\title{
The Cyclic AMP Receptor Protein, Crp, Is Required for the Decolorization of Acid Yellow 36 in Shewanella putrefaciens CN32
}

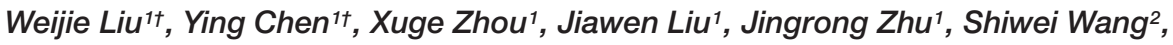 \\ Cong Liu ${ }^{1 *}$ and Di Sun ${ }^{1 *}$
}

1 Jiangsu Key Laboratory of Phylogenomics and Comparative Genomics, School of Life Sciences, Jiangsu Normal University, Xuzhou, China, ${ }^{2}$ Key Laboratory of Resources Biology and Biotechnology in Western China, Ministry of Education, College of Life Science, Northwest University, Xi'an, China

OPEN ACCESS

Edited by:

Lei Chen,

Tianjin University, China

Reviewed by:

Atsushi Kouzuma,

Tokyo University of Pharmacy and Life

Sciences, Japan

Shanshan Liu,

The First Affiliated Hospital of Bengbu

Medical College, China

*Correspondence:

Cong Liu

liucong0426@126.com

Di Sun

sundi047@126.com

${ }^{\dagger}$ These authors have contributed equally to this work

Specialty section: This article was submitted to

Microbiotechnology,

a section of the journa

Frontiers in Microbiology

Received: 19 August 2020 Accepted: 15 October 2020 Published: 09 December 2020

Citation:

Liu W, Chen Y, Zhou X, Liu J, Zhu J, Wang S, Liu C and Sun D (2020) The Cyclic AMP Receptor

Protein, Crp, Is Required for the Decolorization of Acid Yellow 36 in Shewanella putrefaciens CN32.

Front. Microbiol. 11:596372. do: 10.3389/fmicb.2020.596372
Shewanella shows good application potentials in the decolorization and detoxification of azo dye wastewater. However, the molecular mechanism of decolorization is still lacking. In this study, it was found that Shewanella putrefaciens CN32 exhibited good decolorization ability to various azo dyes, and a global regulatory protein cAMP receptor protein (Crp) was identified to be required for the decolorization of acid yellow 36 (AY) by constructing a transposon mutant library. Then, the molecular mechanism of AY decolorization regulated by Crp was further investigated. RT-qPCR and electrophoretic mobility shift assay (EMSA) results showed that Crp was able to directly bind to the promoter region of the cymA gene and promote its expression. Riboflavin acting as an electron shuttle could accelerate the AY decolorization efficiency of $S$. putrefaciens CN32 wild-type (WT) but did not show a promoting effect to $\Delta$ crp mutant and $\Delta c y m A$ mutant, further confirming that Crp promotes the decolorization through regulating electron transport chains. Moreover, the mutant with cymA overexpression could slightly enhance the AY decolorization efficiency compared with the WT strain. In addition, it was found that MtrA, MtrB, and MtrC partially contribute to the electron transfer from CymA to dye molecules, and other main electron transport chains need to be identified in future experiments. This study revealed the molecular mechanism of a global regulator Crp regulating the decolorization of azo dye, which is helpful in understanding the relationship between the decolorization and other metabolic processes in S. putrefaciens CN32.

Keywords: Shewanella putrefaciens CN32, decolorization, azo dye, acid yellow, Crp

\section{INTRODUCTION}

With the rapid development of the textile, printing, and dyeing industries, more than 700,000 tons of commercial synthetic dyes are produced worldwide each year (Guo et al., 2020b), of which azo dyes account for 60-70\% (Hameed and Ismail, 2018; Kong et al., 2018), mainly due to their properties of low cost, easy synthesis, high coloring efficiency, and good stability to various oxidizing agents. The dyeing industries consume huge amounts of azo dyes, and about 10-15\% 
of dye molecules that are not effectively bound to clothing is discharged into the surrounding environment in the form of dyeing wastewater (Zahir et al., 2014; Zhang et al., 2019), causing serious environmental pollution (Yesilada et al., 2003). Dyeing wastewater not only affects the transparency of the surrounding water but also poses a serious threat to the ecological environment and even human health because azo dye molecules and their degradation products have strong mutagenic, teratogenic, and carcinogenic effects (Guo et al., 2020a; Samir et al., 2020). The most remarkable characteristic of azo dyes is that their molecules contain one or more azo groups (Yan et al., 2012). Because of their stubborn structural properties, azo dyes are very stable in nature and difficult to degrade (Liu W. et al., 2017). Therefore, decolorization and detoxification are very necessary before the discharge of azo dye-containing wastewater (Liu et al., 2017b).

Physical, chemical, and biological strategies are generally applied to treat azo dye-containing wastewater (Pandey et al., 2007). Compared with physicochemical methods, which are limited by high energy consumption and secondary pollution, biological methods attracted more and more attention due to their advantages of high decolorization efficiency, low operation cost, and environmental friendliness (Saratale et al., 2011; Samir et al., 2020; Wang et al., 2020). The mechanism of biological decolorization of azo dyes mainly includes bioflocculation (Liu et al., 2009), biological adsorption (Saratale et al., 2011), electron reduction (Cai et al., 2012), and enzymatic degradation (Dawkar et al., 2010; Baweja et al., 2016; Yang et al., 2018, 2020). Moreover, the decolorization efficiency of azo dyes can also be enhanced by the combined use of different biological methods at the same time. For example, the degradation efficiency of insoluble Sudan red can be accelerated by the synergistic effect of enzyme-catalyzed biodegradation and non-specific reductive decolorization (Liu et al., 2018). In addition, much effort has been made to improve the decolorization efficiency of azo dyes (Imran et al., 2016). For example, some electron shuttles, such as riboflavin and methylene blue, have been found to be able to promote electron transfer from the cell surface to the dye molecules, thereby accelerating the biodegradation of azo dyes (Liu et al., 2016).

Many strains have been reported to be able to decolorize azo dyes; among them, Shewanella strains are the most concerned species due to their excellent decolorization performance (Cai et al., 2012; Liu et al., 2016, 2018). Shewanella, as a species of facultative anaerobic bacteria with remarkable respiratory pathways, is able to utilize various terminal electron acceptors under anaerobic conditions, including various pollutants, such as azo dyes and heavy metal ions (Fredrickson et al., 2008; Ding et al., 2014). Therefore, Shewanella strains show good potential in the field of environmental remediation. In Shewanella, many components in the electron transfer pathway are necessary for its decolorization ability (Cai et al., 2012; Xiao et al., 2012; Liu et al., 2016). In the cytomembrane, the tetraheme c-type cytochrome CymA receives electrons from the quinone pool and then transfers them to multiple respiratory pathways, such as Mtr, Dms, NarfA/B, and NrfA pathways (Schwalb et al., 2003; Gao et al., 2009). In Shewanella oneidensis MR-1, the Mtr respiratory pathway, including MtrA, MtrB, MtrC, and OmcA, has been found to be involved in decolorization processes of various azo dyes (Cai et al., 2012; Xiao et al., 2012). However, studies on the molecular mechanism of the decolorization of azo dyes by Shewanella are still lacking, especially on the global regulatory factors related to the decolorization of azo dyes.

In this study, cAMP receptor protein (Crp), a global transcription regulator (Gao et al., 2012), was found to be essential for the decolorization of azo dyes in Shewanella putrefaciens $\mathrm{CN} 32$ through the construction of a transposon mutant library and the selection of mutants with different decolorization abilities and transposon locations. And then, the molecular mechanism of the decolorization of azo dyes regulated by Crp was also investigated. We found that, with the assistance of cAMP, Crp was able to directly bind to the promoter region of the cymA gene and promote its expression, thereby promoting decolorization through regulating electron transport chains. Thus, this study has a certain theoretical significance for revealing the molecular mechanism of the decolorization of azo dyes by Shewanella strains.

\section{MATERIALS AND METHODS}

\section{Bacterial Strains, Plasmids, Primers, and Culture Conditions}

The strains and plasmids used or constructed in this study are shown in Table 1, and the primers used in this study are listed in Table 2. Escherichia coli and S. putrefaciens CN32 strains were grown aerobically at $37^{\circ} \mathrm{C}$ and $30^{\circ} \mathrm{C}$, respectively, in LuriaBertani (LB) medium which contains tryptone $10 \mathrm{~g} / \mathrm{L}$, yeast extract $5 \mathrm{~g} / \mathrm{L}$, and $\mathrm{NaCl} 10 \mathrm{~g} / \mathrm{L}$, for genetic manipulation. If necessary, kanamycin of $50 \mu \mathrm{g} / \mathrm{ml}$ was added into the medium. The decolorization medium for $S$. putrefaciens $\mathrm{CN} 32$ consisted of yeast extract $2 \mathrm{~g} / \mathrm{L}, \mathrm{NH}_{4} \mathrm{Cl} 1 \mathrm{~g} / \mathrm{L}, \mathrm{NaCl} 0.5 \mathrm{~g} / \mathrm{L}, \mathrm{Na}_{2} \mathrm{HPO}_{4} \cdot 12 \mathrm{H}_{2} \mathrm{O}$ $7.52 \mathrm{~g} / \mathrm{L}, \mathrm{NaH}_{2} \mathrm{PO}_{4} \cdot 2 \mathrm{H}_{2} \mathrm{O} 7.13 \mathrm{~g} / \mathrm{L}$, and filter-sterilized sodium lactate $20 \mathrm{mM}$. The transformants were screened on the LKT medium, which is based on the LB medium added with $50 \mu \mathrm{g} / \mathrm{ml}$ of kanamycin and $20 \mu \mathrm{g} / \mathrm{ml}$ of potassium tellurite.

\section{Decolorization Assay of Azo Dyes}

S. putrefaciens CN32 was cultured in LB medium for $12 \mathrm{~h}$ to obtain the seed culture and then inoculated into $60 \mathrm{ml}$ serum vials containing $50 \mathrm{ml}$ of the decolorization medium with azo dyes to an initial $\mathrm{OD}_{600}$ of 0.1 . To ensure anaerobic condition, decolorization systems were purged with nitrogen gas for $2 \mathrm{~min}$. Subsequently, serum vials were sealed with rubber stoppers immediately and then cultured in an incubator at $30^{\circ} \mathrm{C}$ without shaking for decolorization. The decolorization samples of different times were centrifuged at $10,000 \mathrm{rpm}, 25^{\circ} \mathrm{C}$ for $1 \mathrm{~min}$. The absorbance of the supernatant was determined at $497 \mathrm{~nm}$ for Congo red, $520 \mathrm{~nm}$ for amaranth, $414 \mathrm{~nm}$ for acid yellow 36 (AY), $465 \mathrm{~nm}$ for methyl orange, $618 \mathrm{~nm}$ for amino black, and $714 \mathrm{~nm}$ for naphthol green to determine the concentration of residual azo dyes. The decolorization rate (\%) was calculated based on the following equation: (ODx - ODy)/ODx $\times 100 \%$, where ODx and ODy refer to the absorbance of the initial and decolorized 
TABLE 1 | The strains and plasmids used in this study.

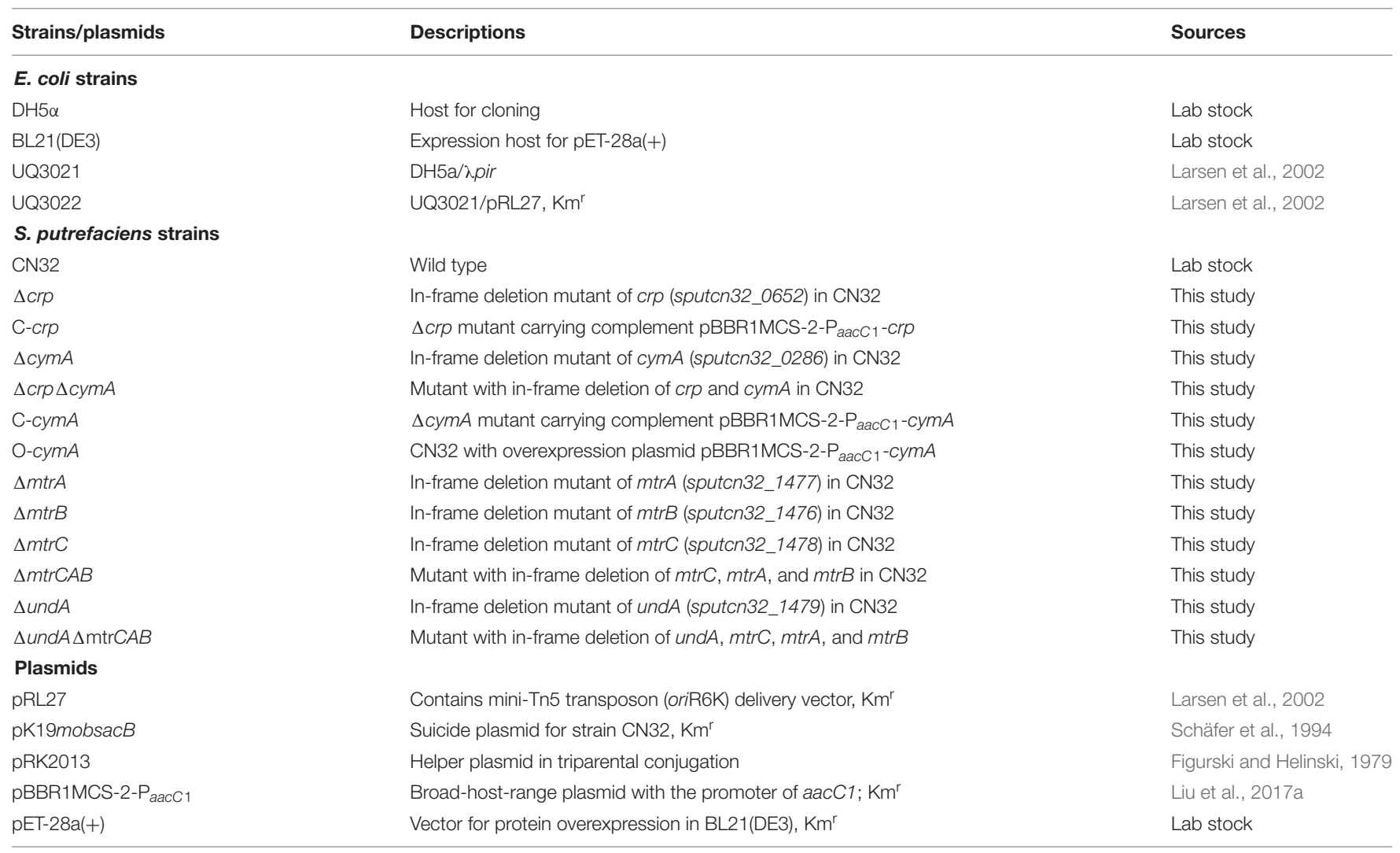

samples, respectively. Experiments were repeated independently at least three times.

\section{Transposon Mutagenesis and Location of Transposon Insertion Sites}

S. putrefaciens CN32 (recipient strain) was mixed with E. coli UQ3022 (donor strain), which carries a plasmid pRL27 containing a mini-Tn5 transposon and a kanamycin resistance gene (Larsen et al., 2002). Both recipient strain and donor strain were cultured overnight in LB medium. The donor strain was washed with LB medium twice and mixed with the recipient strain in a 1:1 ratio. The mixture of these two strains was spotted on a solid LB agar plate and incubated at $30^{\circ} \mathrm{C}$ for $8 \mathrm{~h}$. Then the cells were scraped off from the agar plate and plated onto an LB agar plate with $50 \mu \mathrm{g} / \mathrm{ml}$ of kanamycin and $20 \mu \mathrm{g} / \mathrm{ml}$ of potassium tellurite (to inhibit the cell growth of the donor strain) and incubated at $30^{\circ} \mathrm{C}$ for $36 \mathrm{~h}$. Single black colonies presented were purified, and their decolorization abilities were determined in the decolorization medium with $200 \mathrm{mg} / \mathrm{L} \mathrm{AY}$. The mutants with significantly altered decolorization capacity were selected and preserved. Then, the genomic DNA of these mutants was extracted for localization of the transposon insertion site. The extracted genomic DNA was self-linked after digestion by BamHI or SpeI and then transformed into E. coli UQ3021 (Larsen et al., 2002) and selected on the LB agar plate added with $50 \mu \mathrm{g} / \mathrm{ml}$ of kanamycin. Plasmids extracted from the transformant were sequenced using primer Tn5-seqF and Tn5-seqR and BLAST in NCBI to map the location of the mini-Tn5 transposon. The target genes inserted by the mini-Tn 5 transposon were deleted to confirm its function in regulating AY decolorization in S. putrefaciens CN32.

\section{Construction of Deletion Mutants and Complementation Strains}

The in-frame deletion of mutants for $c r p, m t r A, m t r B, m t r C$, und $A$, and $c y m A$ was performed based on the principle of homologous recombination. The primer positions for the target gene in-frame deletion are shown in Figure $\mathbf{1 A}$, and the genomic arrangement of $m \operatorname{tr} A, m \operatorname{tr} B, \operatorname{mtr} C$, und $A$, and $c y m A$ in $S$. putrefaciens CN32 is shown in Figure 1B. To delete the target gene, approximately 1,000-bp fragments upstream and downstream the targeted gene were amplified with respective primers D5F/D5R and D3F/D3R, using the S. putrefaciens CN32 genome DNA as a PCR template. These two fragments were ligated into the suicide vector pK19mobsacB after being digested by the corresponding restriction endonuclease (Schäfer et al., 1994). Then, the constructed plasmid was transformed into E. coli $\mathrm{DH} 5 \alpha$ and introduced from E. coli $\mathrm{DH} 5 \alpha$ into $S$. putrefaciens CN32 wild type (WT) using a helper plasmid, pRK2013, by triparental conjugation (Figurski and Helinski, 1979). The conjugation experiment was performed according to a previous study (Liu et al., 2017a). Briefly, the donor and recipient strains were conjugated in a 1:1 ratio and spotted on an LB agar plate. LKT medium plates were used to screen for 
TABLE 2 | The primer sequences used in this study.

\begin{tabular}{|c|c|c|c|c|c|}
\hline Primers & Sequences $\left(5^{\prime}-3^{\prime}\right)$ & $\begin{array}{l}\text { Functions or target } \\
\text { genes }\end{array}$ & Primers & Sequences $\left(5^{\prime}-3^{\prime}\right)$ & $\begin{array}{l}\text { Functions or target } \\
\text { genes }\end{array}$ \\
\hline Tn5-seqF & $\begin{array}{l}\text { CAGCAACACC } \\
\text { TTCTTCACGA }\end{array}$ & For Tn5 Sequence & CymA-PR & $\begin{array}{l}\text { AATCATCAAACA } \\
\text { ATCGCAAGTTAT }\end{array}$ & cymA EMSA probe \\
\hline Tn5-seqR & $\begin{array}{l}\text { AACAAGCCAGG } \\
\text { GATGTAACG }\end{array}$ & For Tn5 Sequence & $\begin{array}{l}\text { CymA-QF } \\
\text { CymA-QR }\end{array}$ & $\begin{array}{l}\text { GAACTGGCGT GCACTATT } \\
\text { ATACAGAACT }\end{array}$ & $\begin{array}{l}\text { cymA RT-qPCR } \\
\text { cymA RT-qPCR }\end{array}$ \\
\hline Crp-D5F & CTCAAAGAATTCTAAG & crp deletion & & GATCCGTACTTG & \\
\hline \multirow[t]{2}{*}{ Crp-D5R } & $\begin{array}{l}\text { ATGAGTCCAATCACTGTGCCC } \\
\text { GTATACTCTAGAGGTAC }\end{array}$ & crp deletion & 16S QF & $\begin{array}{l}\text { GCAGGCGGTT } \\
\text { GTTAAGCGAGATG }\end{array}$ & $\begin{array}{l}\text { internal standard for } \\
\text { RT-qPCR }\end{array}$ \\
\hline & CCGTTAAGTTAGTCTTCAGC & & 16S QR & CTTCGCCACCGG & internal standard for \\
\hline Crp-D3F & $\begin{array}{l}\text { TITACTCTAGAGATGTAA } \\
\text { TAAAGGGTATCTGAATCT }\end{array}$ & crp deletion & CymA-FootF & $\begin{array}{l}\text { TATTCCTCCAGA } \\
\text { TGTAAAACGACGGCCA }\end{array}$ & $\begin{array}{l}\text { RT-qPCR } \\
\text { cymA DNase I }\end{array}$ \\
\hline Crp-D3R & $\begin{array}{l}\text { AGGCAGAAGCTTCAGCGA } \\
\text { GGTTATCTAAATTAGTGGG }\end{array}$ & crp deletion & CymA-FootR & $\begin{array}{l}\text { GTAATAATGAACGGCTCGAT } \\
\text { CAGGAAACAGCTATGACCAAT }\end{array}$ & $\begin{array}{l}\text { footprinting } \\
\text { cymA DNase I }\end{array}$ \\
\hline Crp-UF & $\begin{array}{l}\text { GTTGGATACACCAGTG } \\
\text { CGAACAGAC }\end{array}$ & crp deletion & MtrC-D5F & $\begin{array}{l}\text { AGTGCACGCCAGTTC } \\
\text { AAAACTGCAGCTGTGTTAG }\end{array}$ & $\begin{array}{l}\text { footprinting } \\
\text { mtrC deletion }\end{array}$ \\
\hline Crp-DR & TCTAAACTAAGACT & crp deletion & & CTGTCATAATGA & \\
\hline \multirow[t]{2}{*}{ Crp-OF } & $\begin{array}{l}\text { TCTATCAAGTT } \\
\text { CCAGCATGATATG }\end{array}$ & crp deletion & MtrC-D5R & $\begin{array}{l}\text { AAACTTGAAAT } \\
\text { ATTGAAGCC }\end{array}$ & mtrC deletion \\
\hline & $\begin{array}{l}\text { TTCAAGATCTT } \\
\text { GCAGCACTAAAAT }\end{array}$ & crp deletion & MtrC-D3F & $\begin{array}{l}\text { GCAGTGCAG } \\
\text { TCAGAAACC }\end{array}$ & mtrC deletion \\
\hline Crp-OR & CACCAATTTCT & & MtrC-D3R & CCGGAATTCT & mtrC deletion \\
\hline \multirow[t]{2}{*}{ Crp-InF } & CCAАTCTCTTGA & crp deletion & & GCTCACCTCCATGACAT & \\
\hline & CGAGTGATCTTG & & MtrC-UF & GCATTAACTTA & mtrC deletion \\
\hline \multirow[t]{2}{*}{ Crp-InR } & AAGGTTCTGTTG & crp deletion & & AGTCGCCTC & \\
\hline & CCGTATTGATTAA & & MtrC-DR & TGTTCTTCATA & mtrC deletion \\
\hline \multirow[t]{2}{*}{ Crp-CF } & CAAAGGGATCCCGA & crp complementation & & ATAGGCTTCC & \\
\hline & CCACACCATAAAGTTAGCCTG & & MtrC-OF & GTGGTTGTAGCA & mtrC deletion \\
\hline \multirow[t]{2}{*}{ Crp-CR } & TाTAATGAATTCGAA & crp complementation & & GTTGTCATAC & \\
\hline & ACAGGCTTAAATCAAGCTGAAG & & MtrC-OR & ATAATGCCCCTT & mtrC deletion \\
\hline \multirow[t]{2}{*}{ Crp-EF } & ATCAACGGATCCATGGC & express $\mathrm{His}_{6}$-Crp & & ACTACTGG & \\
\hline & TCTGATTGGTAAGCCAAAACC & protein & MtrC-InF & GGTACCTACAG & mtrC deletion \\
\hline \multirow[t]{2}{*}{ Crp-ER } & TGGCCTAAGCTTAGAAT & express $\mathrm{His}_{6}$-Crp & & CTATGACTTCG & \\
\hline & TTATGCTAGGCCACTITAATG & protein & MtrC-InR & TGGTGTAATGT TTGGCGT & mtrC deletion \\
\hline CymA-D5F & $\begin{array}{l}\text { CCGGAATTCCCATTG } \\
\text { CAGTATCGCTTATG }\end{array}$ & cymA deletion & MtrA-D5F & $\begin{array}{l}\text { CCGGAATTCAA } \\
\text { GTATTGTTGACGGTAAGCT }\end{array}$ & mtrA deletion \\
\hline CymA-D5R & $\begin{array}{l}\text { GATACAGAACT } \\
\text { GATCCGTACTTG }\end{array}$ & cymA deletion & MtrA-D5R & $\begin{array}{l}\text { ATAACTCCCTT } \\
\text { CAGCGAAC }\end{array}$ & mtrA deletion \\
\hline CymA-D3F & $\begin{array}{l}\text { GCTCACCCATA } \\
\text { TCCAAAAG }\end{array}$ & cymA deletion & MtrA-D3F & $\begin{array}{l}\text { AATTGCCATA } \\
\text { GTCAGGTTCA }\end{array}$ & mtrA deletion \\
\hline CymA-D3R & $\begin{array}{l}\text { AAAACTGCAGC } \\
\text { TACCTATCCAAGATCTCGAAG }\end{array}$ & cymA deletion & MtrA-D3R & $\begin{array}{l}\text { AAAACTGCAG } \\
\text { CCAGATATCACATTGGTATTGTC }\end{array}$ & mtrA deletion \\
\hline CymA-UF & $\begin{array}{l}\text { TATTGTCCTGAT } \\
\text { AGTTAGAGCT }\end{array}$ & cymA deletion & MtrA-UF & $\begin{array}{l}\text { GCAGTGCAGTC } \\
\text { AGAAACCT }\end{array}$ & mtrA deletion \\
\hline CymA-DR & $\begin{array}{l}\text { CCTGTTAGTITA } \\
\text { TCGTCAGC }\end{array}$ & cymA deletion & MtrA-DR & $\begin{array}{l}\text { AGCCCTTACAG } \\
\text { CTCCATG }\end{array}$ & mtrA deletion \\
\hline CymA-OF & $\begin{array}{l}\text { GCCGAAGACAAA } \\
\text { GAGATAG }\end{array}$ & cymA deletion & MtrA-OF & $\begin{array}{l}\text { TTGAAATTATT } \\
\text { ACTAACGTTGGCC }\end{array}$ & mtrA deletion \\
\hline CymA-OR & AAACCGCCAAAA ATAAAC & cymA deletion & MtrA-OR & CTTGGCTCATT TGTCCCG & mtrA deletion \\
\hline CymA-InF & $\begin{array}{l}\text { CCTGTCACAGC } \\
\text { AАCCATT }\end{array}$ & cymA deletion & MtrA-InF & $\begin{array}{l}\text { GCAATGAACC } \\
\text { GATGATCAC }\end{array}$ & mtrA deletion \\
\hline CymA-InR & $\begin{array}{l}\text { CTGCGGAAATA } \\
\text { CTTAAGTGC }\end{array}$ & cymA deletion & MtrA-InR & $\begin{array}{l}\text { CGTGACAGGC } \\
\text { ATAACAGGT }\end{array}$ & mtrA deletion \\
\hline CymA-CF & $\begin{array}{l}\text { TTCTAAGGATCCTAAGTGAAAT } \\
\text { AGCATAAACTAGACTT }\end{array}$ & cymA complementation & MtrB-D5F & $\begin{array}{l}\text { CCGGAATTCG } \\
\text { CCACCTTAGATAAAAAGTTCG }\end{array}$ & mtrB deletion \\
\hline CymA-CR & $\begin{array}{l}\text { GTTCAAGAATTCGAATGAATCG } \\
\text { CTAAAACCTATTATCC }\end{array}$ & cymA complementation & MtrB-D5R & $\begin{array}{l}\text { AACGATGCA } \\
\text { GCCCTTACAG }\end{array}$ & mtrB deletion \\
\hline CymA-PF & $\begin{array}{l}\text { GACTAAGAGTTTG } \\
\text { ATGCATAAGTATT }\end{array}$ & cymA EMSA probe & MtrB-D3F & $\begin{array}{l}\text { GACGCCGCGA } \\
\text { ATGATATC }\end{array}$ & mtrB deletion \\
\hline
\end{tabular}

(Continued)
TABLE 2 | Continued 
TABLE 2 | Continued

\begin{tabular}{|c|c|c|}
\hline Primers & Sequences $\left(5^{\prime}-3^{\prime}\right)$ & $\begin{array}{l}\text { Functions or target } \\
\text { genes }\end{array}$ \\
\hline MtrB-D3R & $\begin{array}{l}\text { AAAACTGCAG } \\
\text { TGCTAATAAAGATGTCATGGATGC }\end{array}$ & mtrB deletion \\
\hline MtrB-UF & $\begin{array}{l}\text { GCTGCTTAAAT } \\
\text { TGCCATAGT }\end{array}$ & mtrB deletion \\
\hline MtrB-DR & $\begin{array}{l}\text { CTTGTCGTAGC } \\
\text { GCTTAAAC }\end{array}$ & mtrB deletion \\
\hline MtrB-OF & TTGCTACGAGT GCTCATG & mtrB deletion \\
\hline MtrB-OR & $\begin{array}{l}\text { GGCGACTTGCT } \\
\text { TGTAATAT }\end{array}$ & mtrB deletion \\
\hline MtrB-InF & $\begin{array}{l}\text { GGCAAATIT } \\
\text { GACGCTGAC }\end{array}$ & mtrB deletion \\
\hline MtrB-InR & $\begin{array}{l}\text { TACTATCCA } \\
\text { GTTATCAGGCAATGT }\end{array}$ & mtrB deletion \\
\hline UndA-D5F & $\begin{array}{l}\text { AAAACTGCAGA } \\
\text { CTGCGCCTATTGTAGCT }\end{array}$ & und $A$ deletion \\
\hline UndA-D5R & $\begin{array}{l}\text { GGTCAGTACTA } \\
\text { TATCAACGCTG }\end{array}$ & und $A$ deletion \\
\hline UndA-D3F & $\begin{array}{l}\text { AACGGTGGTGT } \\
\text { GTACAATG }\end{array}$ & und $A$ deletion \\
\hline UndA-D3R & $\begin{array}{l}\text { TTGGATCCGCG } \\
\text { AACATAGTTATTCAGTACAAT }\end{array}$ & und $A$ deletion \\
\hline UndA-UF & $\begin{array}{l}\text { TGATGATGATTA } \\
\text { CAACTATTGC }\end{array}$ & und $A$ deletion \\
\hline UndA-DR & $\begin{array}{l}\text { TCTGTCAACTAT } \\
\text { TGCTGCTT }\end{array}$ & und $A$ deletion \\
\hline UndA-OF & $\begin{array}{l}\text { CCGATITCAGA } \\
\text { AATAATGC }\end{array}$ & und $A$ deletion \\
\hline UndA-OR & $\begin{array}{l}\text { AGTAAAGACA } \\
\text { GGTAGCGTGG }\end{array}$ & und $A$ deletion \\
\hline UndA-InF & $\begin{array}{l}\text { TGGATCAGC } \\
\text { TATATCAACTCAGT }\end{array}$ & und $A$ deletion \\
\hline UndA-InR & $\begin{array}{l}\text { GGTGTATCAA } \\
\text { GGTCGGGT }\end{array}$ & und $A$ deletion \\
\hline MtrC-D5F1 & $\begin{array}{l}\text { CCCAAGCTTC } \\
\text { TGTGTTAGCTGTCATAATGA }\end{array}$ & mtrCAB deletion \\
\hline MtrC-D5R1 & $\begin{array}{l}\text { TTGGATCCAAACT } \\
\text { TGAAATATTGAAGCC }\end{array}$ & mtrCAB deletion \\
\hline UndA-D5F1 & $\begin{array}{l}\text { CCCAAGCTTACTGCGCC } \\
\text { TATTGTAGCT }\end{array}$ & mtrCAB/und $A$ deletion \\
\hline UndA-D5R1 & $\begin{array}{l}\text { TTGGATCCGGTCAGTA } \\
\text { CTATATCAACGCTG }\end{array}$ & mtrCAB/und $A$ deletion \\
\hline MtrB-D3F1 & $\begin{array}{l}\text { TTGGATCCGACGCCGC } \\
\text { GAATGATATC }\end{array}$ & mtrCAB/und $A$ deletion \\
\hline MtrB-D3R1 & $\begin{array}{l}\text { AAAACTGCAGTGCTAA } \\
\text { TAAAGATGTCATGGATGC }\end{array}$ & mtrCAB/und $A$ deletion \\
\hline
\end{tabular}

transconjugants after conjugation for $8 \mathrm{~h}$ at $30^{\circ} \mathrm{C}$. The singlecrossover recombinant strain was selected using the primer UF/DR. After overnight culture in the LB medium added with $50 \mu \mathrm{g} / \mathrm{ml}$ of kanamycin, a single-crossover recombinant strain was transferred to a $\mathrm{NaCl}$-free $\mathrm{LB}$ medium in a ratio of $0.1 \%$, and the double-crossover disruptants were screened according to the sucrose sensitivity and finally checked by four pairs of primers: OF/OR, UF/OR, OF/DR, and InF/InR. All the mutants were confirmed by sequencing analysis. For the construction of the $\triangle m \operatorname{tr} C A B$ mutant, upstream and downstream fragments

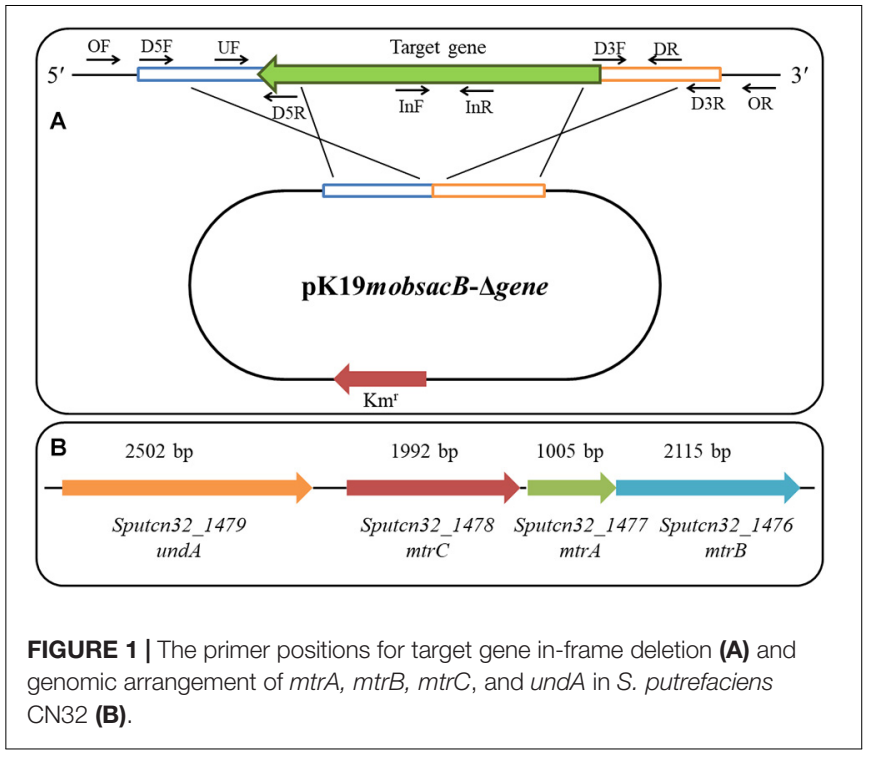

were amplified with primers MtrC-D5F1/MtrC-D5R1 and MtrBD3F1/MtrB-D3R1, respectively, and for the construction of $\triangle u n d A \triangle m \operatorname{tr} C A B$, upstream and downstream fragments were amplified with primers UndA1-D5F1/UndA1-D5R1 and MtrBD3F1/MtrB-D3R1, respectively.

To construct a complementation plasmid, a DNA fragment carrying the ribosome binding site (RBS) and open reading frame (ORF) of the targeted gene was amplified by primers CF/CR using the $S$. putrefaciens CN32 genome as a PCR template and then ligated with the plasmid pBBR1MCS-2-P $\mathrm{P}_{a c C} 1$ with the corresponding restriction site (Liu et al., 2017a). And then the complementation plasmid was introduced into corresponding mutants for complementation or into S. putrefaciens CN32 WT for overexpression.

\section{RNA Extraction and Real-Time RT-PCR Analysis}

In order to analyze the regulatory effect of Crp on the cymA gene, the seed samples of WT and $\Delta c r p$ mutant were inoculated into the decolorization medium with $200 \mathrm{mg} / \mathrm{L}$ AY and cultured for $4 \mathrm{~h}$. The cells were collected by centrifugation at 10,000 rpm, $4^{\circ} \mathrm{C}$ for $5 \mathrm{~min}$, and RNA was extracted by the TRIzol reagent (Tiangen, China) according to the protocol provided by the manufacturer. Real-time RT-PCR was performed using primers CymA-QF/CymA-QR, with SYBR Green Master Mix (Biosharp, China) according to the specification from the manufacturer. Signal intensities of PCR products were standardized to those of the $16 S$ rRNA gene amplified with primers 16S QF/16S QR. The experiments were performed with at least three replicates.

\section{Purification of $\mathrm{His}_{6}-\mathrm{Crp}$ Protein}

To prepare the $\mathrm{His}_{6}$-Crp protein, the coding region of $\mathrm{crp}$ was amplified by PCR using primers Crp-EF/Crp-ER. The PCR product was digested with BamHI/HindIII and cloned into pET-28a $(+)$ to generate pET28-crp. The resulting plasmid was confirmed by sequencing and then transformed 
TABLE 3 | Decolorization ability of S. putrefaciens CN32 to tested azo dyes.

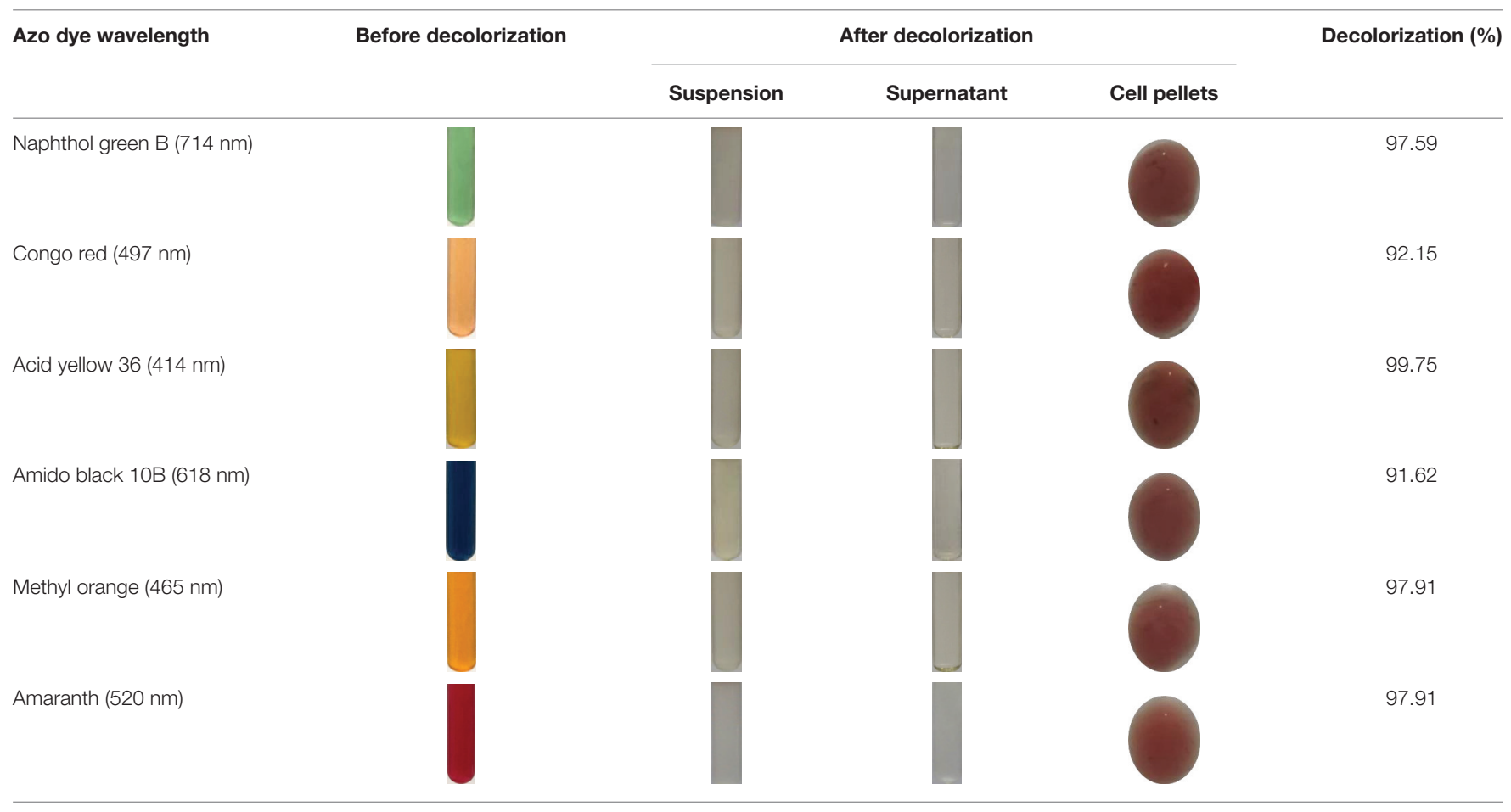

The initial concentration of azo dyes is $50 \mathrm{mg} / \mathrm{L}$. The images of azo dye solution obtained before decolorization and after $24 \mathrm{~h}$ of decolorization. The cell pellets were collected from decolorization solution using a $2 \mathrm{ml}$ tube with 10,000 rpm.

into E. coli BL21(DE3) for overexpression of His $_{6}$-Crp (six-histidine tag on the $\mathrm{N}$-terminus of the Crp protein). After induction with $0.4 \mathrm{mM}$ isopropyl $\beta$-D-thiogalactoside (IPTG) at $16^{\circ} \mathrm{C}$ for $20 \mathrm{~h}$, the soluble recombinant $\mathrm{His}_{6}$-Crp protein was purified by $\mathrm{Ni}$-agarose resin chromatography (CoWin Biosciences, China).

\section{Electrophoretic Mobility Shift Assay (EMSA)}

DNA probe-carrying promoter regions of cymA were PCRamplified by using primers CymA-PF and CymA-PR. The PCR products purified from agarose gel were labeled with digoxigenin (DIG) using terminal transferase. The $3^{\prime}$-terminal DIG-labeled probe of $0.15 \mathrm{nM}$ was incubated with various quantities of $\mathrm{His}_{6}$-Crp and $1 \mu \mathrm{M}$ cAMP in a binding reaction. EMSA experiments were operated as described previously (Sun et al., 2016). To confirm specificity of protein-DNA interaction, a 300-fold excess of unlabeled specific probe or non-specific DNA was added into the binding mixture before incubation.

\section{DNase I Footprinting}

DNase I footprinting assay was carried out to determine the binding site of Crp in the promoter region of cymA. PCR was conducted using 5'-terminal FAM-labeled forward primer CymA-FootF and regular reverse primer CymA-FootR, and the PCR products were purified to obtain FAM-labeled footprinting probes. The mixtures of $20-\mu l$ volume containing various concentrations of purified $\mathrm{His}_{6}-\mathrm{Crp}$, 300-ng probes, and $2 \mu \mathrm{M}$ of cAMP were incubated at $25^{\circ} \mathrm{C}$ for $40 \mathrm{~min}$ to achieve the binding reaction of the Crp protein with the probe. Then $1 \mathrm{U}$ of DNase I (NEB, United States) was added to the mixture and incubated at $37^{\circ} \mathrm{C}$ for $10 \mathrm{~s}$. The DNase I treatment was terminated by adding $10 \mu \mathrm{l}$ of $0.5 \mathrm{M}$ EDTA solution and heated at $80^{\circ} \mathrm{C}$ for $10 \mathrm{~min}$. The DNA fragments were purified and capillary sequenced in a 3730XL DNA Genetic Analyzer (ABI, United States). The data were processed and analyzed with the GeneMarker program, v2.2.0.

\section{Effect of Exogenous Riboflavin on Decolorization}

In order to analyze the effect of exogenous riboflavin on AY decolorization of $S$. putrefaciens CN32 WT, $\Delta c r p$, and $\triangle c y m A$, the strains were cultured in LB medium to an $\mathrm{OD}_{600}$ of around 1.0 and used as seed culture. Then, the cells in seed culture were collected by centrifugation at $25^{\circ} \mathrm{C}, 8,000 \mathrm{rpm}$ for $5 \mathrm{~min}$, and were washed once using the decolorization base medium (decolorization medium without adding yeast extract). The washed cells were inoculated into $60 \mathrm{ml}$ serum vials containing $50 \mathrm{ml}$ of the decolorization base medium with $200 \mathrm{mg} / \mathrm{L}$ of $\mathrm{AY}$ to an initial $\mathrm{OD}_{600}$ of 0.1 . After purging with nitrogen gas for $2 \mathrm{~min}$, the decolorization ability of WT, $\Delta c r p$, and $\triangle c y m A$ with and without adding $2 \mu \mathrm{M}$ riboflavin was determined at different time intervals. 


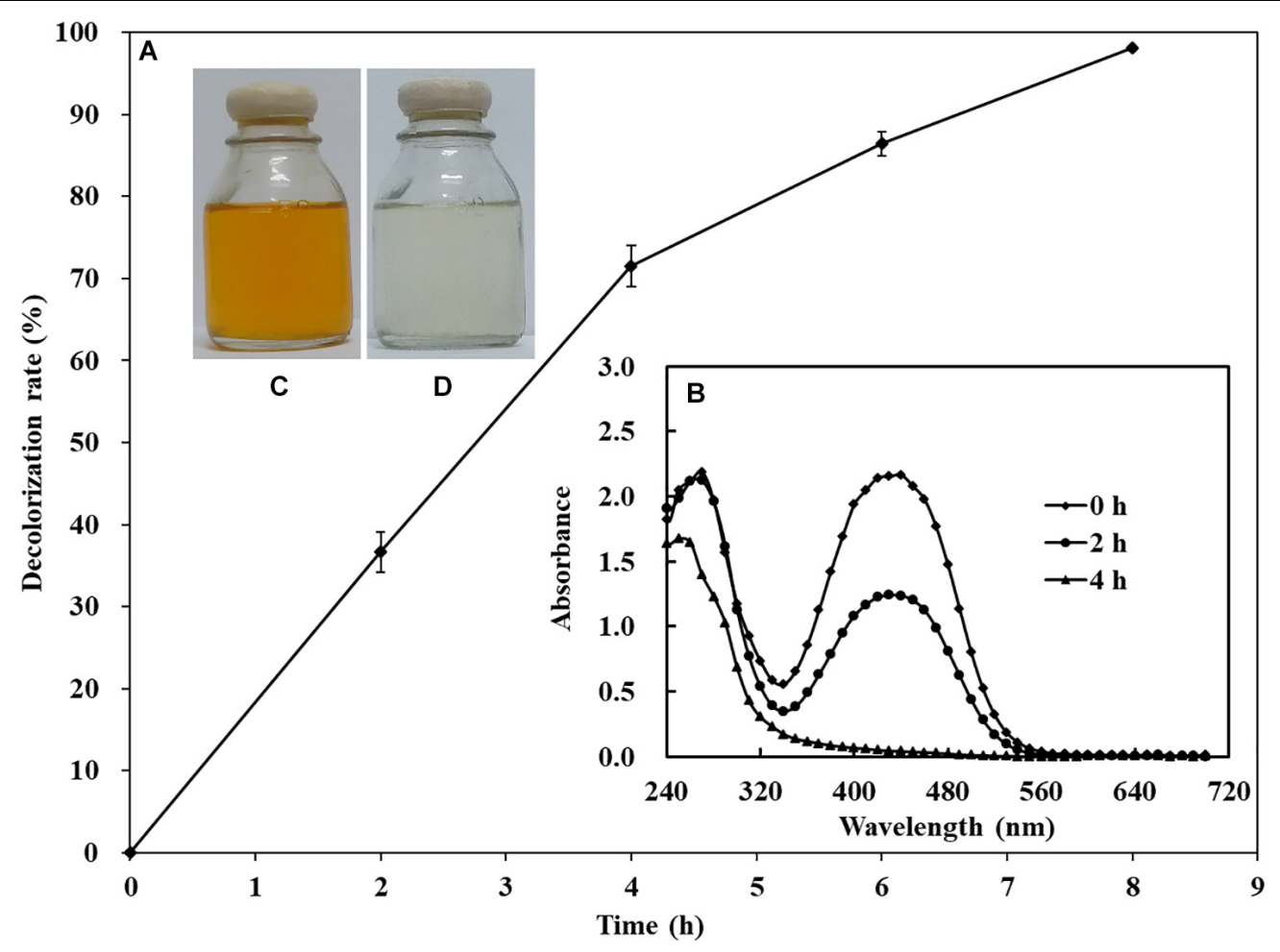

FIGURE 2 | Decolorization of 200 mg/L of AY by S. putrefaciens CN32 (A). Scanning spectrum analysis of 50 mg/L of AY decolorized by S. putrefaciens CN32 at different time intervals (B). The image of $50 \mathrm{mg} / \mathrm{L}$ AY before (C) and after (D) decolorization.

\section{RESULTS AND DISCUSSION}

\section{Decolorization of Various Azo Dyes by S. putrefaciens CN32}

The decolorization ability of $S$. putrefaciens CN32 to various azo dyes was analyzed under anaerobic condition (Table 3). The results showed that $S$. putrefaciens $\mathrm{CN} 32$ was able to decolorize all the tested azo dyes within $48 \mathrm{~h}$. Especially to AY (Figure 2) and methyl orange, more than $90 \%$ of decolorization rates were achieved within $8 \mathrm{~h}$. As shown in Figure 2, the scanning spectrum of AY and its degradation products in a range from 240 to $720 \mathrm{~nm}$ was investigated. It can be seen that the characteristic absorption peak at around $414 \mathrm{~nm}$ disappeared after decolorization of $4 \mathrm{~h}$, suggesting that $S$. putrefaciens $\mathrm{CN} 32$ shows good potential in the treatment of azo dye-containing wastewater. In previous studies, several Shewanella strains have been used to decolorize azo dyes, such as S. oneidensis MR-1 (Liu et al., 2016; Li et al., 2018), Shewanella decolorationis S12 (Xu et al., 2007), Shewanella sp. RQs-106 (Zhou et al., 2018), Shewanella aquimarina (Meng et al., 2012), and Shewanella algae (Meng et al., 2014). In S. oneidensis MR-1, a transmembrane electron transport chain Mtr respiratory pathway, which includes cytochromes MtrC and OmcA and related proteins MtrA and MtrB, has been proven to be responsible for the anaerobic decolorization of azo dyes (Xiao et al., 2012). However, the further regulatory mechanism of the decolorization of azo dyes in Shewanella species is largely unknown. In this study, AY was selected for investigating the molecular mechanism of azo dye decolorization by S. putrefaciens CN32 due to its very high decolorization efficiency.

\section{Crp Promotes the Decolorization Ability of S. putrefaciens CN32 Under Anaerobic Conditions}

To identify the underlying decolorization mechanisms of AY by $S$. putrefaciens $\mathrm{CN} 32$ in anaerobic respiration, approximately 1,000 mini-Tn5 transposon-inserted mutants screened by a kanamycin agar plate were selected for decolorization ability analysis using $60 \mathrm{ml}$ serum vials. Compared with the CN32 WT strain, the decolorization efficiencies of 10 transposon-inserted mutants were significantly altered (more than 50\% change), in which three mutants that exhibited poor decolorization ability to AY were inserted into different sites of the crp gene (sputcn32_0652), suggesting that Crp may be involved in biodecolorization. Thus, an in-frame deletion mutant of the $\operatorname{crp}$ gene $(\Delta c r p)$ and a complementation strain (C-crp) were constructed. As shown in Figure $\mathbf{3 A}$, the anaerobic decolorization efficiency of the $\Delta c r p$ mutant to AY was seriously decreased compared with the WT, and the C-crp mutant was obviously restored to the WT level. At the same time, the growth of WT, $\Delta \operatorname{crp}$ mutant, and C-crp mutant was determined under the anaerobic decolorization condition. The results (Figure 3B) showed that the WT, $\Delta$ crp mutant, and C-crp mutant did not show obvious cell growth during the anaerobic AY decolorization process. Therefore, these results indicated that Crp promotes AY 


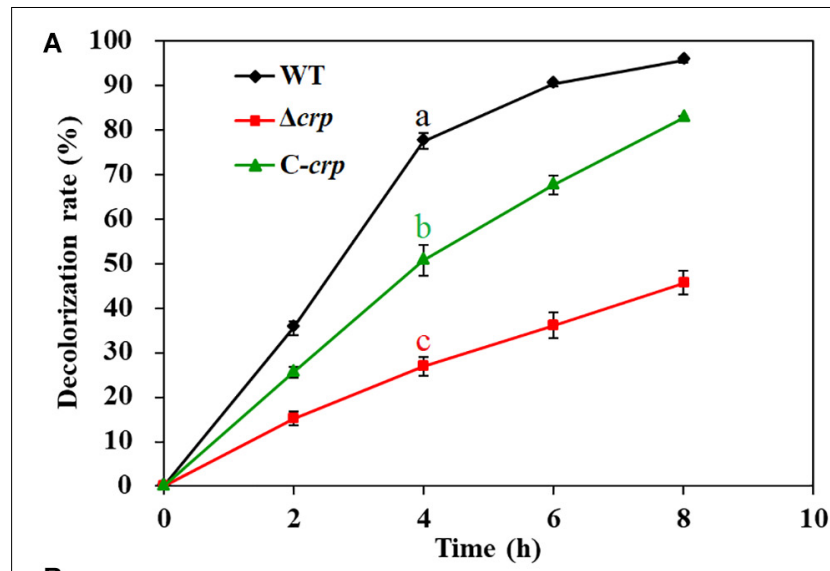

8

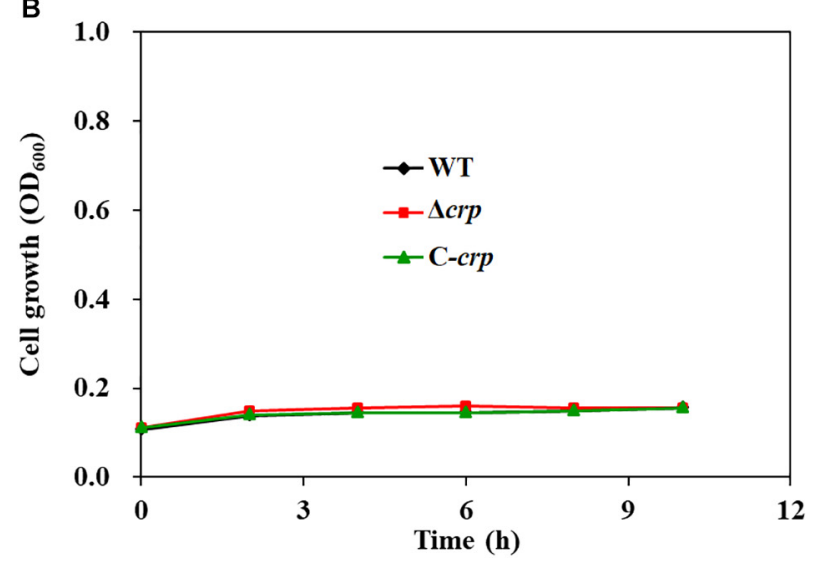

FIGURE 3 | Decolorization of AY (A) and cell growth (B) of the WT, $\Delta$ crp mutant, and C-crp mutant. The initial concentration of AY is $200 \mathrm{mg} / \mathrm{L}$. The cell growth was determined in the decolorization medium under anaerobic conditions. Values for decolorization and cell growth are means $\pm \operatorname{SD}(n=3)$. Significance analysis of decolorization rates of different strains at $4 \mathrm{~h}$ was performed using one-way analysis of variance (ANOVA) with the Tukey-Kramer comparison test $(p<0.05)$.

decolorization in S. putrefaciens CN32. Crp is a global regulatory factor which regulates different metabolic processes in many bacteria by forming complexes with cAMP; for example, Crp is involved in carbon catabolite repression in many bacteria (Deutscher et al., 2006); in E. coli, Crp regulates many stress responses to protect cells from harmful environments including starvation and osmotic shock (Battesti et al., 2011; Kalia et al., 2013); in Pseudomonas aeruginosa, Crp (Vfr) regulates biofilm formation through controlling type IV pili (Beatson et al., 2002; Persat et al., 2015). In this study, it was found that Crp is necessary for biological decolorization in S. putrefaciens CN32.

\section{CymA Is Necessary for the Anaerobic Decolorization of AY in S. putrefaciens CN32}

Except for the crp gene, two transposon-inserted mutants with a significant decrease in decolorization efficiency were identified with different insertion sites in the cymA gene (sputcn32_0286). CymA, a c-type cytochrome, is a component of the Mtr
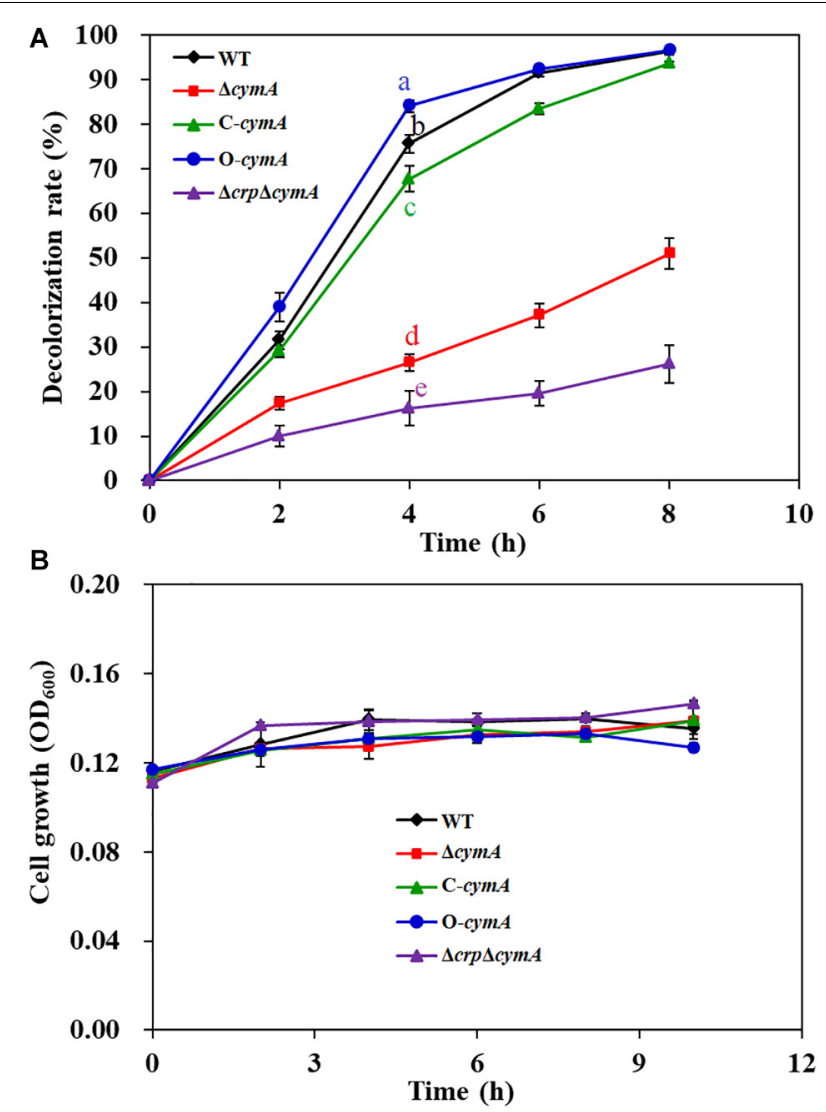

FIGURE 4 | Decolorization of $200 \mathrm{mg} / \mathrm{L}$ of $A Y(\mathbf{A})$ and cell growth (B) of the WT, $\triangle$ cymA mutant, C-cymA mutant, and $\Delta$ crp $\Delta$ cymA mutant. Values for decolorization and cell growth are means $\pm \operatorname{SD}(n=3)$. The cell growth was determined in the decolorization medium under anaerobic conditions. The decolorization rates of different strains at $4 \mathrm{~h}$ were analyzed by ANOVA with the Tukey-Kramer comparison test $(p<0.05)$.

respiratory pathway, which is a critical transmembrane electron transfer channel in dissimilatory metal-reducing strains (Xiao et al., 2012). A previous study showed that the $\Delta c y m A$ mutant of S. oneidensis MR-1 almost lost complete decolorization capability (Xiao et al., 2012). Genome analysis found that the amino acid sequence of CymA in S. putrefaciens CN32 exhibits 95.7\% similarity to that in S. oneidensis MR-1. To confirm the function of CymA in S. putrefaciens CN32 during AY decolorization, an in-frame gene deletion mutant $\triangle c y m A$ and a complementation strain C-cymA were constructed. The anaerobic decolorization ability of the $\triangle c y m A$ mutant was seriously decreased compared with that of the WT strain (Figure 4A); the C-cymA mutant was obviously restored to the WT level. And the WT, $\Delta c y m A$ mutant, and C-cymA mutant exhibited similar cell growth (Figure 4B), suggesting that CymA is necessary for the anaerobic decolorization of AY in S. putrefaciens CN32. As the $\triangle$ cymA mutant showed a similar phenotype to the $\Delta \operatorname{crp}$ mutant, a double mutant $\Delta c r p \Delta c y m A$ was constructed to analyze their relationship. The results showed that the $\Delta \operatorname{crp} \Delta c y m A$ mutant exhibited a similar decolorization efficiency to the $\Delta c r p$ and 

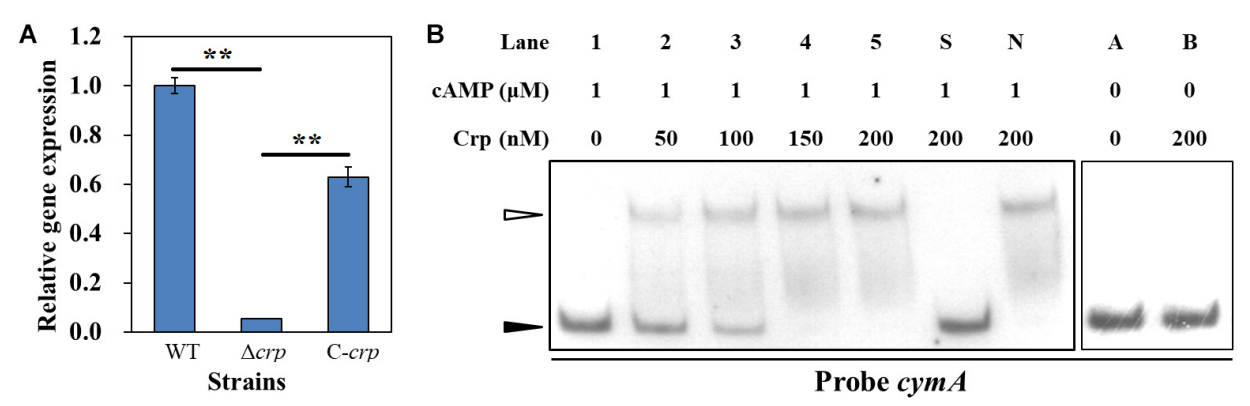

C

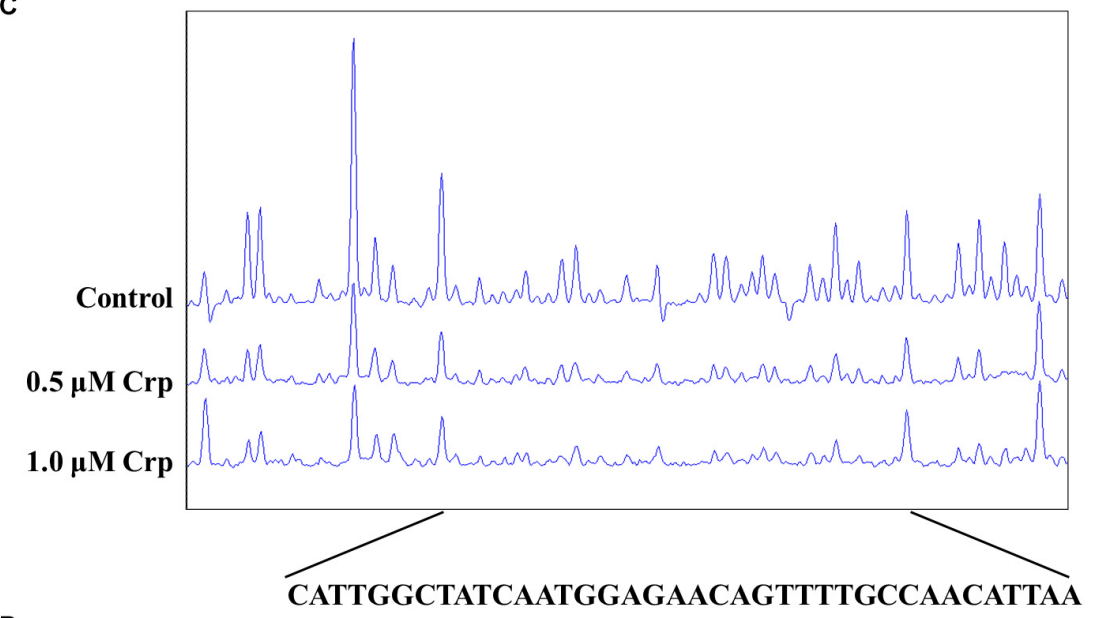

D TCTCAATGAGATACCCATTGGCTATCAATGGAGAACAGTTTTGCCAACATTAATATTGGT AGAGTTACTCTATGGGTAACCGATAGTTACCTCTTGTCAAAACGGTTGTAATTATAACCA

cymA start codon

+270 ACTAATTTTGGCAATTTTGGAGATAGAGTAATGAACTGGCGTGCACTATTTAAACCTAGC

FIGURE 5 | Regulatory effect of Crp on cymA gene. (A) The relative expression level of the cymA gene in the WT, $\triangle$ crp mutant, and C-crp mutant. cymA expression level in the WT strain was normalized as 1. Error bars indicate standard deviation of three samples. Significance analysis was performed using Student's $t$-test; ${ }^{* *} p<0.01$. (B) EMSAs of the interaction of different concentrations of $\mathrm{His}_{6}$-Crp with DNA probes; $0.15 \mathrm{nM}$ labeled probe and $1.0 \mu \mathrm{M}$ cAMP were added to reaction mixtures with different concentrations of His 6 -Crp (Lanes 1, 2, 3, 4, and 5). A 300-fold-excess unlabeled specific competitor (Probe cymA, Lane S) and non-specific competitor (Lane N) were added to the mixture to perform specific or non-specific competition assays, respectively. Lanes A and B: Reaction mixtures without addition of CAMP used as negative controls. Filled triangles: Free probes. Empty triangle: Protein-DNA complex. (C) DNase I footprinting assay of different concentrations $(0.5$ and $1.0 \mu \mathrm{M})$ of $\mathrm{His}_{6}-\mathrm{Crp}$ and cymA in the upstream region. Each reaction mixture contains 300-ng FAM-labeled DNA probe and $2 \mu \mathrm{M}$ cAMP. Control: No His 6 -Crp protein in the reaction mixture. The nucleotide sequences of the protected region were shown below the graph. (D) Nucleotide sequences of cymA promoter region and His,-Crp binding site. Bent arrow: Predicted cymA TSS. Shaded region: Region protected by Crp in the DNase I footprinting assay. Underline: cymA start codon. Numbers indicate the distance (nt) from TSS.

$\triangle$ cymA mutants, which is obviously lower than that of the WT strain, indicating that Crp and CymA may be involved in the same decolorization pathway.

\section{Crp Directly Activates the Transcription of cymA}

Crp is a critical global transcriptional regulator in prokaryotes through forming a complex with cAMP. In S. oneidensis MR-1, the complex of Crp and cAMP can regulate the transcription of multiple cytochrome $\mathrm{c}$ genes including omcA and $m \operatorname{trC}$ (Kasai et al., 2015). However, the relationship between Crp and the cymA gene is still unclear. To determine whether Crp regulates the transcription of the cymA gene in S. putrefaciens $\mathrm{CN} 32$, real-time reverse-transcription PCR (RT-qPCR) was carried out (Figure 5A). Compared with that in the WT strain, the cymA expression level in the $\Delta c r p$ mutant was significantly decreased, and almost no cymA expression was detected in the $\Delta c r p$ 


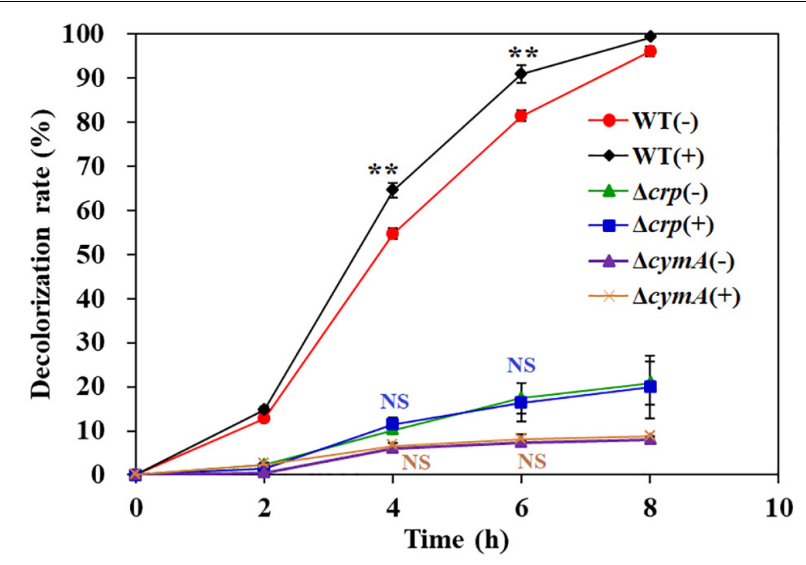

FIGURE 6 | The effect of exogenous riboflavin on AY decolorization. Values are means $\pm \operatorname{SD}(n=3)$. The cells were cultured in decolorization medium with (+) or without (-) adding $2 \mu \mathrm{M}$ riboflavin. The initial AY concentration of is $200 \mathrm{mg} / \mathrm{L}$. Significance analysis of decolorization rates of the same strain with and without riboflavin was performed using Student's $t$-test; asterisks ${ }^{\star \star} p<0.01$, and NS indicates not significant.

mutant, indicating that Crp plays a critical role in activating the expression of the $c y m A$ gene. To identify the regulation that Crp exerts on the transcription of the cymA gene, EMSA was performed to investigate whether Crp directly binds to the upstream regions of the $c y m A$ gene. When a labeled DNA probe containing the region from -183 to -477 bp upstream of $c y m A$ was incubated with the Crp-cAMP complex, shifted bands were observed (Figure 5B). When there is no cAMP in the mixture, no shifted band was observed (Figure 5B). These findings suggested that the Crp-cAMP complex can bind to the promoter region of the $c y m A$ gene. Taken together, Crp directly activates the transcription of the cymA gene through forming a complex with cAMP. To further investigate the mechanism by which the CrpcAMP complex activates $c y m A$, a DNase I footprinting assay was carried out to identify the precise binding site of the CrpcAMP complex at the upstream regions of the cymA gene, and a protected region from -375 to $-338 \mathrm{nt}$ upstream of the cymA start codon was revealed (Figure 5C). Subsequently, the transcription start site (TSS) of cymA was predicted using an online BDGM promoter prediction tool ${ }^{1}$. A possible TSS was found to be a "G" located at $300 \mathrm{nt}$ upstream of the cymA start codon (Figure 5D). Based on the above results, it is possible that the Crp-cAMP complex activates cymA expression by recruiting the RNA polymerase to the promoter region of $c y m A$.

\section{Effect of Exogenous Riboflavin on Decolorization}

Previous studies have reported that flavins produced from Shewanella genus (Marsili et al., 2008) and other chemical substances, such as methylene blue (Liu et al., 2016) and humic acids (Liu et al., 2011), were able to act as shuttles to accelerate the electron transfer from the cell surface to pollutant molecules,

${ }^{1}$ https://fruitfly.org/seq_tools/promoter.html

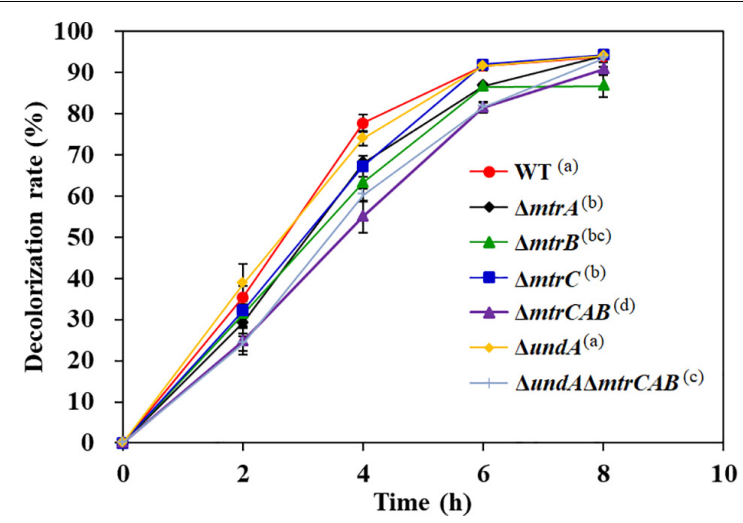

FIGURE 7 | The decolorization of $200 \mathrm{mg} / \mathrm{L}$ AY by the WT and Mtr pathway mutants. Values are means $\pm \mathrm{SD}(n=3)$. The decolorization rates of different strains at $4 \mathrm{~h}$ were analyzed by ANOVA with the Tukey-Kramer comparison test $(p<0.05)$.

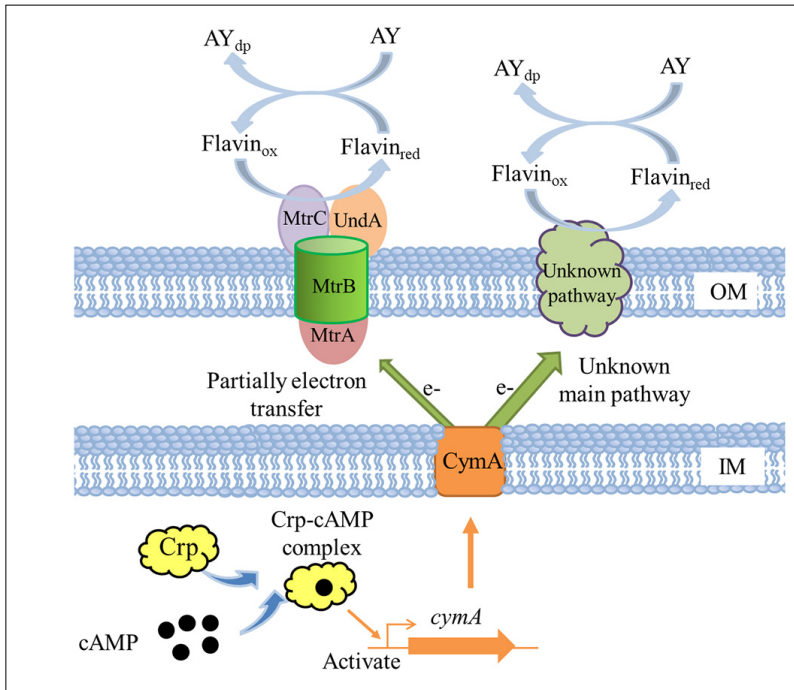

FIGURE 8 | A proposed molecular model of Crp regulating AY decolorization in S. putrefaciens CN32. OM indicates outer membrane; IM indicates inner membrane; $A Y_{d p}$ indicates degradation products of acid yellow.

such as azo dyes and heavy metal ions. In order to analyze the effect of electron shuttle on AY decolorization by $S$. putrefaciens $\mathrm{CN} 32,2 \mu \mathrm{M}$ riboflavin was added into the decolorization systems of WT, $\Delta c r p$, and $\triangle c y m A$. The results showed that riboflavin could significantly improve the decolorization efficiency of the WT strain, but no significant promotion effect was observed for the $\Delta c r p$ mutant and $\Delta c y m A$ mutant (Figure 6). These results further demonstrated that the regulation of Crp to the AY decolorization efficiency is achieved by regulating the members of electron transport chains including CymA.

\section{Analysis of the Electron Transport Pathway From CymA to AY}

CymA is an electron transfer hub supporting multi-branched respiratory chains (Marritt et al., 2012). Recent studies showed 
that the Mtr respiratory pathway of S. oneidensis MR-1 not only participates in the dissimilatory reduction of multiple metal ions (Toporek et al., 2019) but also plays a critical role in the decolorization process of a variety of textile dyes (Cai et al., 2012). Genome analysis found that an $m t r$-like gene cluster exists in the genome of $S$. putrefaciens CN32, including MtrC, MtrA, MtrB, and UndA, and their amino acid sequences exhibit 53.5, 88.6, 83.4, and 26.6\% similarity to MtrC, MtrA, $\mathrm{MtrB}$, and OmcA, respectively, in S. oneidensis MR-1. To determine whether the Mtr respiratory pathway is involved in AY decolorization in $S$. putrefaciens CN32, the in-frame deletion mutants $\triangle m t r C, \triangle m t r A, \triangle m t r B$, and $\triangle u n d A$ and the triple mutants $\triangle m \operatorname{tr} C A B$ and $\triangle$ und $\triangle \mathrm{m} \operatorname{tr} C A B$ were constructed. As shown in Figure 7, $\Delta m \operatorname{tr} C, \Delta m \operatorname{tr} A, \triangle m \operatorname{tr} B, \triangle u n d A, \triangle m \operatorname{tr} C A B$, and $\triangle$ und $A m \operatorname{tr} C A B$ showed 10.6, 9.8, 14.5, 3.8, 22.8, and $17.6 \%$ decreases in the decolorization efficiency of AY at $4 \mathrm{~h}$, respectively, indicating that the Mtr respiratory pathway only partially contributes to the transfer of electron required for the AY decolorization process in S. putrefaciens CN32. This is consistent with the results previously reported (Xiao et al., 2012). At the same time, we also noticed that the blocking of the Mtr pathway could not completely inhibit the AY decolorization efficiency and that the influence of the Mtr pathway on the decolorization of MR-1 was more significant than that of CN32. In S. putrefaciens CN32, the decolorization efficiency of Mtr mutants (except $\triangle$ cymA mutant) decreased only about $20 \%$ compared with the WT strain; however, in S. oneidensis MR1 , a decrease of more than $60 \%$ in decolorization efficiency was reported (Xiao et al., 2012), indicating that MtrA, MtrB, and MtrC only partially contribute to the AY decolorization in S. putrefaciens CN32. This is similar to the latest published result, which showed that MtrA, MtrB, and MtrC did not play a major role in the decolorization of methyl orange by $S$. putrefaciens CN32 under microaerobic conditions in 96-well plates (Min et al., 2020). Thus, S. putrefaciens CN32 exhibits a more complex electron transfer process than did S. oneidensis MR-1 in the decolorization of azo dyes. Therefore, it is necessary to identify other main electron transfer pathways from the CymA electron transfer hub to azo dye acceptors in future studies.

\section{Mechanism of Crp Regulating the AY Decolorization in S. putrefaciens CN32}

A molecular mechanism model of Crp regulating AY biodecolorization was proposed in Figure 8. Crp and cAMP form a complex and then directly activate the transcription of $c y m A$; MtrA, MtrB, and MtrC partially contribute to electron transfer from cells to AY acceptors, and other major electron transfer pathways from CymA to dye molecules need to be identified in future studies; flavin acts as a shuttle to accelerate the electron transfer from cells to dye molecules through the switch between the oxidation state and reduction state. AY dye molecules are decomposed into colorless degradation products under the action of electron reduction. Based on the above molecular regulation mechanism, we tried to improve the decolorization ability of S. putrefaciens $\mathrm{CN} 32$ by overexpression of $\operatorname{cymA}$ in the WT strain
(O-cymA mutant). The result showed that the decolorization ability of the O-cymA mutant was slightly improved compared to that of the WT strain. The above results indicate that Crp is necessary to activate the expression of $c y m A$, thereby promoting AY decolorization through accelerating electron transfer from cells to dye molecules.

\section{CONCLUSION}

In this study, AY was selected as an electron acceptor to reveal the molecular mechanism of $S$. putrefaciens CN32 decolorization of azo dyes. By constructing a transposon mutant library, the cAMP receptor protein Crp was identified as a necessary regulator for AY decolorization in S. putrefaciens CN32. Crp can directly bind to the promoter region of the cymA gene and activate the expression of the cymA gene, thereby supporting AY decolorization. MtrA, MtrB, and MtrC partially contribute to the electron transfer from CymA to AY molecules, and other major electron transfer pathways need to be identified in future studies. Furthermore, the overexpression of cymA could slightly enhance the decolorization efficiency of AY in S. putrefaciens CN32. This study will help us understand the molecular mechanism of azo dye decolorization in other Shewanella strains.

\section{DATA AVAILABILITY STATEMENT}

The raw data supporting the conclusions of this article will be made available by the authors, without undue reservation.

\section{AUTHOR CONTRIBUTIONS}

WL and CL designed the research. WL and YC performed decolorization experiments. YC and $\mathrm{XZ}$ operated gene deletion and complementation experiments. JL and JZ carried out protein expression and purification experiments. YC, SW, and DS performed RNA extraction, RT-qPCR and DNase I footprinting assays. WL, CL, and DS wrote and revised the manuscript. All authors contributed to the article and approved the submitted version.

\section{FUNDING}

This study is supported by the National Natural Science Foundation of China (31970036, 31900401, and 31800020), Natural Science Foundation of Jiangsu Province (BK20171163 and BK20181009), Natural Science Foundation of Xuzhou City (KC19196), Six Talent Peaks Project of Jiangsu Province (JNHB-103), Qing Lan Project of Jiangsu Province, Postgraduate Research \& Practice Innovation Program of Jiangsu Province (2019XKT404), and Priority Academic Program Development of Jiangsu Higher Education Institutions. 


\section{REFERENCES}

Battesti, A., Majdalani, N., and Gottesman, S. (2011). The RpoS-mediated general stress response in Escherichia coli. Annu. Rev. Microbiol. 65, 189-213. doi: 10.1146/annurev-micro-090110-102946

Baweja, M., Nain, L., Kawarabayasi, Y., and Shukla, P. (2016). Current technological improvements in enzymes toward their biotechnological applications. Front. Microbiol. 7:965. doi: 10.3389/fmicb.2016.00965

Beatson, S. A., Whitchurch, C. B., Sargent, J. L., Levesque, R. C., and Mattick, J. S. (2002). Differential regulation of twitching motility and elastase production by Vfr in Pseudomonas aeruginosa. J. Bacterial 184, 3605-3613. doi: 10.1128/jb. 184.13.3605-3613.2002

Cai, P. J., Xiao, X., He, Y. R., Li, W. W., Chu, J., Wu, C., et al. (2012). Anaerobic biodecolorization mechanism of methyl orange by Shewanella oneidensis MR-1. Appl. Microbiol. Biotechnol. 93, 1769-1776. doi: 10.1007/s00253-011$3508-8$

Dawkar, V. V., Jadhav, U. U., Tamboli, D. P., and Govindwar, S. P. (2010). Efficient industrial dye decolorization by Bacillus sp. VUS with its enzyme system. Ecotoxicol. Environ. Saf. 73, 1696-1703. doi: 10.1016/j.ecoenv.2010.07.002

Deutscher, J., Francke, C., and Postma, P. W. (2006). How phosphotransferase system-related protein phosphorylation regulates carbohydrate metabolism in bacteria. Microbiol. Mol. Biol. Rev. 70, 939-1031. doi: 10.1128/MMBR.00024-06

Ding, Y., Peng, N., Du, Y., Ji, L., and Cao, B. (2014). Disruption of putrescine biosynthesis in Shewanella oneidensis enhances biofilm cohesiveness and performance in $\mathrm{Cr}(\mathrm{VI})$ immobilization. Appl. Environ. Microbiol. 80, 14981506. doi: 10.1128/AEM.03461-13

Figurski, D. H., and Helinski, D. R. (1979). Replication of an origin-containing derivative of plasmid RK2 dependent on a plasmid function provided in trans. Proc. Natl. Acad. Sci. U.S.A. 76, 1648-1652. doi: 10.1073/pnas.76.4.1648

Fredrickson, J. K., Romine, M. F., Beliaev, A. S., Auchtung, J. M., Driscoll, M. E., Gardner, T. S., et al. (2008). Towards environmental systems biology of Shewanella. Nat. Rev. Microbiol. 6, 592-603. doi: 10.1038/nrmicro1947

Gao, C., Mulder, D., Yin, C., and Elliot, M. A. (2012). Crp is a global regulator of antibiotic production in Streptomyces. mBio 3:e00407-12. doi: 10.1128/mBio. 00407-12

Gao, H., Yang, Z. K., Barua, S., Reed, S. B., and Zhou, J. (2009). Reduction of nitrate in Shewanella oneidensis depends on atypical NAP and NRF systems with NapB as a preferred electron transport protein from CymA to NapA. ISME J. 3:966. doi: 10.1038 /ismej.2009.40

Guo, G., Hao, J., Tian, F., Liu, C., Ding, K., Xu, J., et al. (2020a). Decolorization and detoxification of azo dye by halo-alkaliphilic bacterial consortium: systematic investigations of performance, pathway and metagenome. Ecotoxicol. Environ. Saf. 204:111073. doi: 10.1016/j.ecoenv.2020.111073

Guo, G., Li, X., Tian, F., Liu, T., Yang, F., Ding, K., et al. (2020b). Azo dye decolorization by a halotolerant consortium under microaerophilic conditions. Chemosphere 244: 125510. doi: 10.1016/j.chemosphere.2019.125510

Hameed, B. B., and Ismail, Z. Z. (2018). Decolorization, biodegradation and detoxification of reactive red azo dye using non-adapted immobilized mixed cells. Biochem. Eng. J. 137, 71-77. doi: 10.1016/j.bej.2018.05.018

Imran, M., Arshad, M., Negm, F., Khalid, A., Shaharoona, B., Hussain, S., et al. (2016). Yeast extract promotes decolorization of azo dyes by stimulating azoreductase activity in Shewanella sp. strain IFN4. Ecotoxicol. Environ. Saf. 124, 42-49. doi: 10.1016/j.ecoenv.2015.09.041

Kalia, D., Merey, G., Nakayama, S., Zheng, Y., Zhou, J., Luo, Y., et al. (2013). Nucleotide, c-di-GMP, c-di-AMP, cGMP, cAMP,(p) ppGpp signaling in bacteria and implications in pathogenesis. Chem. Soc. Rev. 42, 305-341. doi: 10.1039/ c2cs35206k

Kasai, T., Kouzuma, A., Nojiri, H., and Watanabe, K. (2015). Transcriptional mechanisms for differential expression of outer membrane cytochrome genes omcA and $m t r C$ in Shewanella oneidensis MR-1. BMC Microbiol. 15:68. doi: 10.1186/s12866-015-0406-8

Kong, F., Ren, H.-Y., Pavlostathis, S. G., Wang, A., Nan, J., and Ren, N.-Q. (2018). Enhanced azo dye decolorization and microbial community analysis in a stacked bioelectrochemical system. Chem. Eng. J. 354, 351-362. doi: 10.1016/ j.cej.2018.08.027

Larsen, R. A., Wilson, M. M., Guss, A. M., and Metcalf, W. W. (2002). Genetic analysis of pigment biosynthesis in Xanthobacter autotrophicus Py2 using a new, highly efficient transposon mutagenesis system that is functional in a wide variety of bacteria. Arch. Microbiol. 178, 193-201. doi: 10.1007/s00203-0020442-2

Li, Q., Feng, X., Lu, X., Li, T., Han, X., Xiao, X., et al. (2018). Combined intra-and extracellular reduction involved in the anaerobic biodecolorization of cationic azo dye by Shewanella oneidensis MR-1. Chemosphere 211, 701-708. doi: 10. 1016/j.chemosphere.2018.08.006

Liu, C., Yang, J., Liu, L., Li, B., and Liu, W. (2017a). Sodium lactate negatively regulates biofilm formation of Shewanella putrefaciens CN32 via a threecomponent regulatory system (LrbS-LrBA-LrbR). Appl. Environ. Microbiol. 83:AEM.00712-17. doi: 10.1128/AEM.00712-17

Liu, C., You, Y., Zhao, R., Sun, D., Zhang, P., Jiang, J., et al. (2017b). Biosurfactant production from Pseudomonas taiwanensis L1011 and its application in accelerating the chemical and biological decolorization of azo dyes. Ecotoxicol. Environ. Saf. 145, 8-15. doi: 10.1016/j.ecoenv.2017.07.012

Liu, G., Zhou, J., Wang, J., Wang, X., Jin, R., and Lv, H. (2011). Decolorization of azo dyes by Shewanella oneidensis MR-1 in the presence of humic acids. Appl. Microbiol. Biotechnol. 91, 417-424. doi: 10.1007/s00253-011-3273-8

Liu, W., Liu, C., Liu, L., You, Y., Jiang, J., Zhou, Z., et al. (2017). Simultaneous decolorization of sulfonated azo dyes and reduction of hexavalent chromium under high salt condition by a newly isolated salt-tolerant strain Bacillus circulans BWL1061. Ecotoxicol. Environ. Saf. 141, 9-16. doi: 10.1016/j.ecoenv. 2017.03.005

Liu, W., Liu, L., Liu, C., Hao, Y., Yang, H., Yuan, B., et al. (2016). Methylene blue enhances the anaerobic decolorization and detoxication of azo dye by Shewanella onediensis MR-1. Biochem. Eng. J. 110, 115-124. doi: 10.1016/j.bej. 2016.02.012

Liu, W., You, Y., Sun, D., Wang, S., Zhu, J., and Liu, C. (2018). Decolorization and detoxification of water-insoluble Sudan dye by Shewanella putrefaciens CN32 co-cultured with Bacillus circulans BWL1061. Ecotoxicol. Environ. Saf. 166, 11-17. doi: 10.1016/j.ecoenv.2018.09.055

Liu, W. J., Yuan, H. L., Yang, J. S., and Li, B. Z. (2009). Characterization of bioflocculants from biologically aerated filter backwashed sludge and its application in dying wastewater treatment. Bioresour. Technol. 100, 2629-2632. doi: 10.1016/j.biortech.2008.12.017

Marritt, S. J., Lowe, T. G., Bye, J., McMillan, D. G., Shi, L., Fredrickson, J., et al. (2012). A functional description of CymA, an electron-transfer hub supporting anaerobic respiratory flexibility in Shewanella. Biochem. J. 444, 465-474. doi: 10.1042/BJ20120197

Marsili, E., Baron, D. B., Shikhare, I. D., Coursolle, D., Gralnick, J. A., and Bond, D. R. (2008). Shewanella secretes flavins that mediate extracellular electron transfer. Proc. Natl. Acad. Sci. U.S.A. 105, 3968-3973. doi: 10.1073/pnas. 0710525105

Meng, X., Liu, G., Zhou, J., and Fu, Q. S. (2014). Effects of redox mediators on azo dye decolorization by Shewanella algae under saline conditions. Bioresour. Technol. 151, 63-68. doi: 10.1016/j.biortech.2013.09.131

Meng, X., Liu, G., Zhou, J., Fu, Q. S., and Wang, G. (2012). Azo dye decolorization by Shewanella aquimarina under saline conditions. Bioresour. Technol. 114, 95-101. doi: 10.1016/j.biortech.2012.03.003

Min, D., Cheng, L., Liu, D.-F., Li, W.-W., and Yu, H.-Q. (2020). Electron transfer via the non-Mtr respiratory pathway from Shewanella putrefaciens $\mathrm{CN}-32$ for methyl orange bioreduction. Process Biochem. 95, 108-114. doi: 10.1016/j. procbio.2020.05.015

Pandey, A., Singh, P., and Iyengar, L. (2007). Bacterial decolorization and degradation of azo dyes. Int. Biodeter. Biodegr. 59, 73-84. doi: 10.1016/j.ibiod. 2006.08.006

Persat, A., Inclan, Y. F., Engel, J. N., Stone, H. A., and Gitai, Z. (2015). Type IV pili mechanochemically regulate virulence factors in Pseudomonas aeruginosa. Proc. Natl. Acad. Sci. U.S.A. 112, 7563-7568. doi: 10.1073/pnas.1502025112

Samir, S., Al-Tohamy, R., Kenawy, E. R., and Sun, J. (2020). Performance of a newly isolated salt-tolerant yeast strain Sterigmatomyces halophilus SSA-1575 for azo dye decolorization and detoxification. Front. Microbiol. 11:1163. doi: 10.3389/fmicb.2020.01163

Saratale, R. G., Saratale, G. D., Chang, J.-S., and Govindwar, S. P. (2011). Bacterial decolorization and degradation of azo dyes: a review. J. Taiwan Inst. Chem. E. 42, 138-157. doi: 10.1016/j.jtice.2010.06.006

Schäfer, A., Tauch, A., Jäger, W., Kalinowski, J., Thierbach, G., and Pühler, A. (1994). Small mobilizable multi-purpose cloning vectors derived from the Escherichia coli plasmids pK18 and pK19: selection of defined deletions in the 
chromosome of Corynebacterium glutamicum. Gene 145, 69-73. doi: 10.1016/ 0378-1119(94)90324-7

Schwalb, C., Chapman, S. K., and Reid, G. A. (2003). The tetraheme cytochrome CymA is required for anaerobic respiration with dimethyl sulfoxide and nitrite in Shewanella oneidensis. Biochemistry 42, 9491-9497. doi: 10.1021/bi034456f

Sun, D., Zhu, J., Chen, Z., Li, J., and Wen, Y. (2016). SAV742, a novel AraC-family regulator from Streptomyces avermitilis, controls avermectin biosynthesis, cell growth and development. Sci. Rep. 6:36915. doi: 10.1038/srep36915

Toporek, Y. J., Mok, J. K., Shin, H. D., Lee, B. D., Lee, M. H., and DiChristina, T. J. (2019). Metal reduction and protein secretion genes required for iodate reduction by Shewanella oneidensis. Appl. Environ. Microbiol. 85:e02115-18. doi: 10.1128/AEM.02115-18

Wang, X., Wang, Y., Ning, S., Shi, S., and Tan, L. (2020). Improving azo dye decolorization performance and halotolerance of Pichia occidentalis A2 by static magnetic field and possible mechanisms through comparative transcriptome analysis. Front. Microbiol. 11:712. doi: 10.3389/fmicb.2020.00712

Xiao, X., Xu, C.-C., Wu, Y.-M., Cai, P.-J., Li, W.-W., Du, D.-L., et al. (2012). Biodecolorization of Naphthol Green B dye by Shewanella oneidensis MR1 under anaerobic conditions. Bioresour. Technol. 110, 86-90. doi: 10.1016/j. biortech.2012.01.099

$\mathrm{Xu}$, M., Guo, J., and Sun, G. (2007). Biodegradation of textile azo dye by Shewanella decolorationis S12 under microaerophilic conditions. Appl. Microbiol. Biotechnol. 76, 719-726. doi: 10.1007/s00253-007-1032-7

Yan, B., Du, C., Xu, M., and Liao, W. (2012). Decolorization of azo dyes by a salt-tolerant Staphylococcus cohnii strain isolated from textile wastewater. Front. Env. Sci. Eng. 6:806-814.

Yang, Q., Zhang, M., Zhang, M., Wang, C., Liu, Y., Fan, X., et al. (2018). Characterization of a novel, cold-adapted, and thermostable laccase-like enzyme with high tolerance for organic solvents and salt and potent dye decolorization ability, derived from a marine metagenomic library. Front. Microbiol. 9:2998. doi: 10.3389/fmicb.2018.02998

Yang, X., Wu, Y., Zhang, Y., Yang, E., and Yan, J. (2020). A thermo-active laccase isoenzyme from Trametes trogii and its potential for dye decolorization at high temperature. Front. Microbiol. 11:241. doi: 10.3389/fmicb.2020.00241

Yesilada, O., Asma, D., and Cing, S. (2003). Decolorization of textile dyes by fungal pellets. Process Biochem. 38, 933-938. doi: 10.1016/S0032-9592(02)00197-8

Zahir, H., Naidoo, M., Kostadinova, R.-M., Ortiz, K. A., Sun-Kou, R., and Navarro, A. E. (2014). Decolorization of hair dye by lignocellulosic waste materials from contaminated waters. Front. Environ. Sci. 2:28. doi: 10.3389/fenvs.2014.00028

Zhang, F., Guo, X., Qian, D.-K., Sun, T., Zhang, W., Dai, K., et al. (2019). Decolorization of Acid Orange 7 by extreme-thermophilic mixed culture. Bioresour. Technol. 291:121875. doi: 10.1016/j.biortech.2019.121875

Zhou, Y., Lu, H., Wang, J., Zhou, J., Leng, X., and Liu, G. (2018). Catalytic performance of quinone and graphene-modified polyurethane foam on the decolorization of azo dye Acid Red 18 by Shewanella sp. RQs-106. J. Hazard. Mater. 356, 82-90. doi: 10.1016/j.jhazmat.2018.05.043

Conflict of Interest: The authors declare that the research was conducted in the absence of any commercial or financial relationships that could be construed as a potential conflict of interest.

Copyright ( $2020 \mathrm{Liu}$, Chen, Zhou, Liu, Zhu, Wang, Liu and Sun. This is an openaccess article distributed under the terms of the Creative Commons Attribution License (CC BY). The use, distribution or reproduction in other forums is permitted, provided the original author(s) and the copyright owner(s) are credited and that the original publication in this journal is cited, in accordance with accepted academic practice. No use, distribution or reproduction is permitted which does not comply with these terms. 